Check for updates

Cite this: RSC Adv., 2017, 7, 24129

\title{
Grandiflodines A and B, two novel diterpenoid alkaloids from Delphinium grandiflorum $\uparrow$
}

\author{
Neng-Hua Chen, ${ }^{\text {ab }}$ Yu-Bo Zhang, ${ }^{\text {ab }}$ Wen Li, ${ }^{\text {ab }}$ Pan Li, ${ }^{\text {ab }}$ Li-Feng Chen, ${ }^{\text {ab }}$ Yao-Lan Li, ${ }^{\text {ab }}$ \\ Guo-Qiang Li ${ }^{\star C}$ and Guo-Cai Wang*ab
}

Two novel diterpenoid alkaloids, grandiflodines A and B (1 and 2), were isolated from Delphinium grandiflorum. Compound 1 represents a rare hetisine-type $\mathrm{C}_{20}$-diterpenoid alkaloid in which the bond between the atoms of $\mathrm{N}$ and $\mathrm{C}-17$ is broken. Compound 2 features an unusual lycoctonine-type $\mathrm{C}_{19}$ diterpenoid alkaloid skeleton with the cleavage of $\mathrm{N}-\mathrm{C}_{19}$ and $\mathrm{C}_{7}-\mathrm{C}_{17}$ bonds, and the construction of the $\mathrm{N}-\mathrm{C}_{7}$ bond. Structural elucidations of the isolates were performed by spectroscopic analysis, $\mathrm{X}$-ray diffraction and comparison with the literature. These compounds were tested for their antiviral and antiinflammatory activities.

Received 9th March 2017 Accepted 26th April 2017

DOI: $10.1039 / \mathrm{c} 7 \mathrm{ra02869e}$

rsc.li/rsc-advances

People's Republic of Mongolia. ${ }^{9}$ As a folk medicine, the $D$. grandiflorum is applied for the treatment of toothache, and used as native pesticide as well. ${ }^{9}$ As part of our ongoing research on the bioactive natural products from Delphinium plants, ${ }^{\mathbf{1 0}}$ an extensive phytochemical investigation on D. grandiflorum was undertaken, leading to the isolation of two novel diterpenoid alkaloids, grandiflodines $\mathrm{A}$ and $\mathrm{B}$ ( $\mathbf{1}$ and $\mathbf{2}$ ). Compound $\mathbf{1}$ is a rare hetisine-type $\mathrm{C}_{20}$-diterpenoid alkaloid with the cleavage of the bond between the atoms of $\mathrm{N}$ and $\mathrm{C}-17$. Compound 2 features an unusual lycoctonine-type $\mathrm{C}_{19}$-diterpenoid alkaloid skeleton with the cleavage of $\mathrm{N}-\mathrm{C}_{19}$ and $\mathrm{C}_{7}-\mathrm{C}_{17}$ bonds, and construction of the $\mathrm{N}-\mathrm{C}_{7}$ bond. Herein, we report the isolation, structure elucidation and biological activities of 1 and 2 (Fig. 1). target for medicinal chemists. ${ }^{8}$

Delphinium grandiflorum is a perennial herb mainly distributed in the Northwest of China and some regions of Siberia and
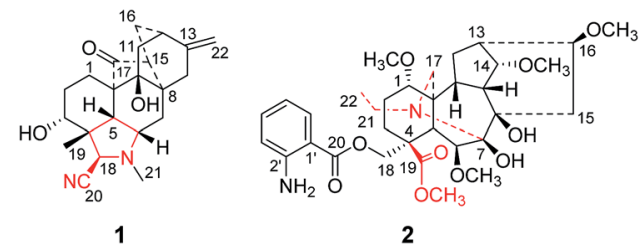

Fig. 1 Chemical structures of compounds 1 and 2 .

\footnotetext{
${ }^{a}$ Institute of Traditional Chinese Medicine \& Natural Products, College of Pharmacy, Jinan University, Guangzhou 510632, P. R. China. E-mail: twangguocai@jnu.edu.cn ${ }^{b}$ Guangdong Province Key Laboratory of Pharmacodynamic Constituents of TCM and New Drugs Research, Jinan University, Guangzhou 510632, P. R. China

'Foshan University, Foshan, 528000, P. R. China. E-mail: liguoqiang@jnu.edu.cn $\dagger$ Electronic supplementary information (ESI) available: UV, IR, HRESIMS and NMR spectra of compounds 1 and 2. CCDC 1517870. For ESI and crystallographic data in CIF or other electronic format see DOI: $10.1039 / \mathrm{c} 7 \mathrm{ra02869e}$
}

\section{Results and discussion}

Grandiflodine A (1) was isolated as colorless block crystal. The molecular formula of 1 was established as $\mathrm{C}_{22} \mathrm{H}_{28} \mathrm{~N}_{2} \mathrm{O}_{3}$ by its HR-ESI-MS $\left(m / z\right.$ 369.2175 $[\mathrm{M}+\mathrm{H}]^{+}$, calcd for $\mathrm{C}_{22} \mathrm{H}_{29} \mathrm{~N}_{2} \mathrm{O}_{3}$ : 369.2173). The UV spectrum of $\mathbf{1}$ displayed the absorption maxima at $208 \mathrm{~nm}$, and its IR spectrum showed the characteristic absorptions for hydroxyl groups $\left(3479,3423 \mathrm{~cm}^{-1}\right)$, cyanogroup (2228 $\mathrm{cm}^{-1}$ ) and carbonyl group $\left(1673 \mathrm{~cm}^{-1}\right)$. The ${ }^{1} \mathrm{H}$ NMR and HSQC spectroscopic data of 1 provided the resonances for two methyls $\left[\delta_{\mathrm{H}} 1.18,2.26\right.$ (each $\left.\left.3 \mathrm{H}, \mathrm{s}\right) ; \delta_{\mathrm{C}} 25.6,33.4\right]$, an olefinic methylene $\left[\delta_{\mathrm{H}} 4.51,4.67\right.$ (each $\left.1 \mathrm{H}, \mathrm{d}, J=1.8 \mathrm{~Hz}\right) ; \delta_{\mathrm{C}}$ $103.4]$ and an oxygenated methine $\left[\delta_{\mathrm{H}} 3.36(1 \mathrm{H}, \mathrm{t}, J=5.8 \mathrm{~Hz}) ; \delta_{\mathrm{C}}\right.$ 72.9]. The ${ }^{13} \mathrm{C}$ and DEPT NMR data exhibited 22 signals of two methyls, seven methylenes, six methines and seven quaternary carbons, including a cyanogroup $\left(\delta_{\mathrm{C}}\right.$ 117.6), a pair of double bond $\left(\delta_{\mathrm{C}} 103.4,150.3\right)$ and a carbonyl group $\left(\delta_{\mathrm{C}} 216.9\right)$. Detailed comparison of the ${ }^{1} \mathrm{D}$ NMR data of 1 (Table 1 ) with those of anhydroignavinol ${ }^{\mathbf{1 1}}$ showed that they were similar except for the presence of additional carbonyl and cyanogroup, and the 
Table 1 NMR spectroscopic data for grandiflodines A (1) and B (2) ( $\delta$ in ppm)

\begin{tabular}{|c|c|c|c|c|}
\hline \multirow[b]{2}{*}{ Position } & \multicolumn{2}{|c|}{ Grandiflodine A (1) ${ }^{a}$} & \multicolumn{2}{|c|}{ Grandiflodine A $(2)^{b}$} \\
\hline & $\delta_{\mathrm{C}}$ & $\begin{array}{l}\delta_{\mathrm{H}} \\
(J \text { in } \mathrm{Hz})\end{array}$ & $\delta_{\mathrm{C}}$ & $\begin{array}{l}\delta_{\mathrm{H}} \\
(J \text { in } \mathrm{Hz})\end{array}$ \\
\hline 1 & 23.2 & $\begin{array}{l}1.62 \\
1.06 \mathrm{~m}\end{array}$ & 88.9 & $\begin{array}{l}2.88 \mathrm{dd} \\
(10.8,4.1)\end{array}$ \\
\hline 2 & 26.6 & $\begin{array}{l}2.60 \mathrm{~m} \\
1.62\end{array}$ & 21.7 & $\begin{array}{l}1.98 \mathrm{~m} \\
1.75 \mathrm{~m}\end{array}$ \\
\hline 3 & 72.9 & $3.36 \mathrm{t}(5.8)$ & 30.1 & $\begin{array}{l}2.34 \mathrm{~m} \\
1.44 \mathrm{~m}\end{array}$ \\
\hline 4 & 47.7 & - & 49.8 & - \\
\hline 5 & 53.5 & 2.30 & 49.9 & $2.02 \mathrm{~d}(6.7)$ \\
\hline 6 & 58.6 & $3.07 \mathrm{~m}$ & 90.5 & $3.71 \mathrm{~m}$ \\
\hline 7 & 31.2 & $\begin{array}{l}2.30 \\
1.75 \mathrm{dd} \\
(14.8,4.5)\end{array}$ & 87.8 & - \\
\hline 8 & 39.6 & - & 82.0 & - \\
\hline 9 & 76.5 & - & 39.9 & $2.30 \mathrm{~m}$ \\
\hline 10 & 51.7 & - & 51.3 & $1.89 \mathrm{~m}$ \\
\hline 11 & 38.7 & $\begin{array}{l}1.86 \\
1.38 \mathrm{dd} \\
(14.1,2.6)\end{array}$ & 42.7 & - \\
\hline 12 & 35.9 & 2.16 & 29.6 & $\begin{array}{l}1.83 \mathrm{~m} \\
1.35 \mathrm{~m}\end{array}$ \\
\hline 13 & 150.3 & - & 45.3 & $2.43 \mathrm{~m}$ \\
\hline 14 & 32.7 & $\begin{array}{l}1.62 \\
1.56 \mathrm{dd} \\
(12.8,4.3)\end{array}$ & 85.3 & $3.66 \mathrm{t}(3.9)$ \\
\hline 15 & 49.2 & 2.30 & 33.2 & $\begin{array}{l}2.37 \mathrm{~m} \\
1.57 \mathrm{dd} \\
(13.8,8.1)\end{array}$ \\
\hline 16 & 31.2 & $\begin{array}{l}1.70 \mathrm{~d}(14.5) \\
2.16\end{array}$ & 84.2 & $3.12 \mathrm{~m}$ \\
\hline 17 & 216.9 & - & 42.3 & $\begin{array}{l}2.99 \mathrm{~d}(11.0) \\
2.65 \mathrm{~d}(11.0)\end{array}$ \\
\hline 18 & 55.3 & $3.81 \mathrm{~s}$ & 70.5 & $\begin{array}{l}4.66 \mathrm{~d}(10.9) \\
4.15 \mathrm{~d}(10.9)\end{array}$ \\
\hline 19 & 25.6 & $1.18 \mathrm{~s}$ & 174.9 & - \\
\hline 20 & 117.6 & - & 167.7 & - \\
\hline 21 & 33.4 & $2.26 \mathrm{~s}$ & 43.7 & $\begin{array}{l}3.15 \mathrm{~m} \\
2.75 \mathrm{~m}\end{array}$ \\
\hline 22 & 103.4 & $\begin{array}{l}4.51 \\
4.67 \mathrm{~d}(1.8)\end{array}$ & 13.7 & $1.02 \mathrm{t}(6.9)$ \\
\hline $3-\mathrm{OH}$ & & $5.00 \mathrm{~d}(5.5)$ & & \\
\hline 9-OH & & $4.86 \mathrm{~s}$ & & \\
\hline $1-\mathrm{OCH}_{3}$ & & & 56.8 & $3.24, \mathrm{~s}$ \\
\hline $6-\mathrm{OCH}_{3}$ & & & 61.3 & $3.62, \mathrm{~s}$ \\
\hline $14-\mathrm{OCH}_{3}$ & & & 57.9 & $3.38, \mathrm{~s}$ \\
\hline $16-\mathrm{OCH}_{3}$ & & & 56.4 & $3.28, \mathrm{~s}$ \\
\hline $19-\mathrm{OCH}_{3}$ & & & 52.1 & $3.72, \mathrm{~s}$ \\
\hline $1^{\prime}$ & & & 110.7 & \\
\hline $2^{\prime}$ & & & 150.8 & \\
\hline $3^{\prime}$ & & & 117.0 & $6.64, \mathrm{~m}$ \\
\hline $4^{\prime}$ & & & 134.4 & $7.24, \mathrm{~m}$ \\
\hline $5^{\prime}$ & & & 116.5 & $6.58, \mathrm{~m}$ \\
\hline $6^{\prime}$ & & & 131.0 & $\begin{array}{l}7.71, \mathrm{dd} \\
(8.0,1.4)\end{array}$ \\
\hline
\end{tabular}

${ }^{a}$ Measured at 500/125 MHz in DMSO- $d_{6} \cdot{ }^{b}$ Measured at $300 / 75 \mathrm{MHz}$ in $\mathrm{CDCl}_{3}$. Overlapped signals are reported without designating multiplicity.

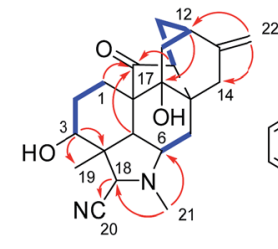

1

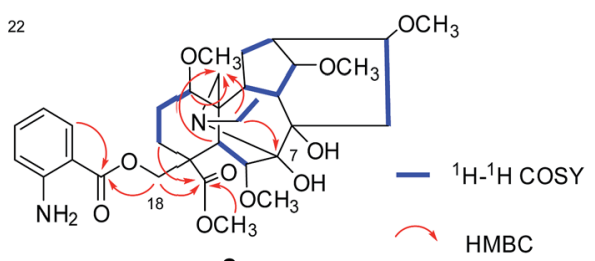

2
Fig. 2 Key ${ }^{1} \mathrm{H}-{ }^{1} \mathrm{H}$ COSY and $\mathrm{HMBC}$ correlations of 1 and 2.

absence of two oxygenated methines in 1. In the HMBC spectrum, the correlations (Fig. 2) between $\mathrm{H}-1 / \mathrm{H}-5 / \mathrm{H}-15$ and the carbonyl group $\left(\delta_{\mathrm{C}} 216.9\right)$ revealed that the carbonyl group was located at C-17. Moreover, the HMBC correlations between $\mathrm{H}-21$ $\left[\delta_{\mathrm{H}} 2.26,(3 \mathrm{H}, \mathrm{s})\right]$ and $\mathrm{C}-6 / \mathrm{C}-18$ suggested that the methyl $\left(\delta_{\mathrm{C}}\right.$ 33.4, C-21) was connected to the nitrogen atom. The above information implied that the $\mathrm{N}-\mathrm{C}_{17}$ bond was broken to form a unique hetidines-type $\mathrm{C}_{20}$-diterpenoid alkaloid skeleton as depicted. In addition, the cyanogroup $\left(\delta_{\mathrm{C}} 117.6\right)$ was located at C-18 based upon the HMBC correlation between H-18 and C-20 $\left(\delta_{\mathrm{C}}\right.$ 117.6). And the HMBC correlations between $\mathrm{H}-3\left(\delta_{\mathrm{H}} 3.36\right.$, $1 \mathrm{H}, \mathrm{t}, J=5.8 \mathrm{~Hz}$ ) and C-4/C-18/C-19, between $\mathrm{H}-11 / \mathrm{H}-12 / \mathrm{H}-15 /$ $\mathrm{H}-16$ and $\mathrm{C}-9\left(\delta_{\mathrm{C}} 76.5\right)$ indicated that the carbons at C-3 and C-9 were substituted by hydroxyls, respectively. In light of the evidences mentioned above, the planar structure of $\mathbf{1}$ was finally established.

The relative configuration of $\mathbf{1}$ could be elucidated by the NOESY experiment. The correlations (Fig. 3) between 3-OH and $\mathrm{H}-18$, between $\mathrm{H}-19$ and $\mathrm{H}-3 / \mathrm{H}-5 / \mathrm{H}-6$, as well as between $9-\mathrm{OH}$ and $\mathrm{H}-5$ established the relative configuration of $\mathbf{1}$. Finally, the structure and configuration were further elucidated by an X-ray diffraction analysis (Fig. 4). The final refinement of the $\mathrm{Cu} \mathrm{K} \alpha$ data resulted in a small flack parameter of -0.05 (6) allowing the assignment of the absolute configuration of 1 as $3 R, 4 R, 5 R$, $6 S, 8 S, 9 S, 10 S, 12 S, 15 S, 18 R$.

The molecular formula of 2 was deduced as $\mathrm{C}_{33} \mathrm{H}_{48} \mathrm{~N}_{2} \mathrm{O}_{10}$ by HR-ESI-MS at $m / z 633.3387[\mathrm{M}+\mathrm{H}]^{+}$(calcd for $\mathrm{C}_{33} \mathrm{H}_{49} \mathrm{~N}_{2} \mathrm{O}_{10}$ : 633.3382). The ${ }^{1} \mathrm{H}$ NMR spectrum of 2 displayed the signals of one ortho-substituted benzene ring at $\delta_{\mathrm{H}} 7.71(1 \mathrm{H}, \mathrm{dd}, J=8.0$, $1.4 \mathrm{~Hz}), 7.24(1 \mathrm{H}, \mathrm{m}), 6.64(1 \mathrm{H}, \mathrm{m}), 6.58(1 \mathrm{H}, \mathrm{m})$, and five methoxyls at $\delta_{\mathrm{H}} 3.72,3.62,3.38,3.28,3.24$ (each $3 \mathrm{H}, \mathrm{s}$ ). The ${ }^{13} \mathrm{C}$ and DEPT NMR data displayed thirty-three carbon signals including six methyls, seven methylenes, thirteen methines and seven quaternary carbons. Detailed analysis of the ${ }^{1} \mathrm{H}$ and ${ }^{13} \mathrm{C}$ NMR data (Table 1) of 2 showed a number of similarities to those of anthranoyllycoctonine. ${ }^{12}$ The most notable differences were the existence of an additional carbonyl $\left(\delta_{\mathrm{C}} 174.9\right)$ and an

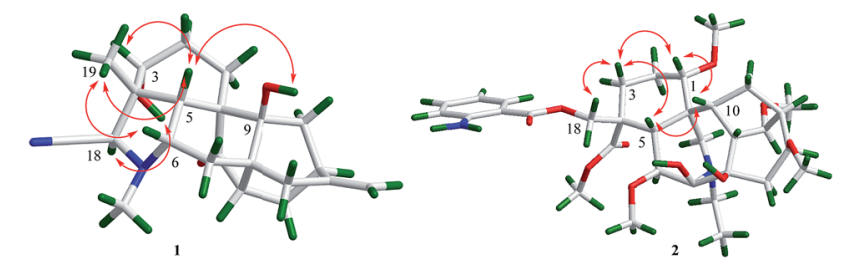

Fig. 3 NOESY correlations of 1 and 2. 


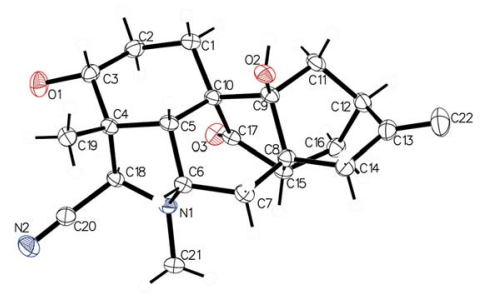

Fig. 4 Perspective drawing of the $X$-ray structure of 1

additional methoxyl $\left(\delta_{\mathrm{C}}\right.$ 52.1) in 2. The HMBC correlations between $\mathrm{H}-3 / \mathrm{H}-18$ and $\mathrm{C}-19\left(\delta_{\mathrm{C}} 174.9\right)$, and between $19-\mathrm{OCH}_{3}\left(\delta_{\mathrm{C}}\right.$ 52.1) and $\mathrm{C}-19$ indicated that the $\mathrm{N}-\mathrm{C}_{19}$ bond was broken, and the carbon at $\mathrm{C}-19$ was oxidized to be carbonyl. Furthermore, the HMBC correlations between $\mathrm{H}-1 / \mathrm{H}-5 / \mathrm{H}-21$ and the methylene at $\mathrm{C}-17\left(\delta_{\mathrm{C}} 42.3\right)$ revealed that the $\mathrm{C}_{7}-\mathrm{C}_{17}$ linkage was broken. In addition, the correlation from $\mathrm{H}-21$ to $\mathrm{C}-7$ suggested that a new bond was constructed between the nitrogen atom and C-7. Hence, the planar structure of 2 was established. The relative configuration of 2 was the same as that of anthranoyllycoctonine by interpretation of the NOESY data (Fig. 3). ${ }^{\mathbf{1 2}}$

Compounds 1 and 2 were tested for their antiviral effect against the respiratory syncytial virus (RSV), and antiinflammatory activity on Nitric Oxide (NO) production. Both the two compounds showed no cell cytotoxicity towards the tested cells with the $\mathrm{CC}_{50}$ values more than $100 \mu \mathrm{M}$. Compound 2 displayed weak inhibitory effect on the growth of RSV and the production of NO in tested cells with the $\mathrm{IC}_{50}$ values of 75.3 and $72.7 \mu \mathrm{M}$, respectively, and $\mathbf{1}$ was virtually inactive with $\mathrm{IC}_{50}$ values more than $100 \mu \mathrm{M}$.

\section{Conclusions}

In summary, compounds $\mathbf{1}$ and $\mathbf{2}$, two novel diterpenoid alkaloids were isolated from $D$. grandiflorum. Compound 1 represents a rare hetisine-type $\mathrm{C}_{20}$-diterpenoid alkaloid, and 2 features an unusual lycoctonine-type $\mathrm{C}_{19}$-diterpenoid alkaloid skeleton, revealing that the alkaloids in Delphinium plants possess complex structure skeletons and adding the diversity of alkaloid compositions isolated from Delphinium plants. Moreover, the assays of anti-RSV and anti-inflammatory activities showed that these two compounds had little cytotoxicity towards the tested cells, providing more potentiality for further pharmacologic study.

\section{Experimental section}

\section{General}

Melting point was obtained on an X-5 microscopic melting point apparatus. Optical rotations were recorded on a digital JASCO P-2000 polarimeter. UV spectra were obtained using a JASCO V-550 UV/VIS spectrophotometer. IR spectra were measured on a JASCO FT/IR-480 plus FT-IR spectrometer. NMR spectra were obtained by Bruker AV-500/300 spectrometers, with TMS as an internal standard. The chemical shifts $(\delta)$ were expressed in ppm and coupling constants $(J)$ in Hz. HR-ESI-MS data was recorded on an Agilent 6210 ESI/TOF mass spectrometer. Analytical HPLC was performed using a Dionex ultimate 3000 system with a Cosmosil $\mathrm{C}_{18}$ analytical column $(5 \mu \mathrm{m}$, $4.6 \times 250 \mathrm{~mm})$. Preparative HPLC was performed using an Agilent 1100 liquid chromatograph with a Cosmosil $\mathrm{C}_{18}$ preparative column $(5 \mu \mathrm{m}, 20 \times 250 \mathrm{~mm})$. Column chromatographies were performed with silica gel (80-100, 200-300, 300-400 mesh; Qingdao Marine Chemical Group Co. Ltd, Qingdao, China), ODS (50 $\mu \mathrm{m}, 120 \AA$ A; YMC) and Sephadex LH-20 (Pharmacia Biotech, Uppsala, Sweden). Silica gel $\mathrm{GF}_{254}$ plates (Yantai Chemical Industry Research Institute, Yantai, China) were used for thin-layer chromatography (TLC). Fractions were monitored by TLC, and spots were detected with modified Dragendorff's reagent.

\section{Plant material}

The dried rhizomes of $D$. grandiflorum were purchased in Guangzhou, Guangdong Province of China, in July, 2015. The plant was authenticated by Prof. Guang-Xiong Zhou (College of Pharmacy, Jinan University). A voucher specimen (no. 150713) was deposited in the Institute of Traditional Chinese Medicine and Natural Products, Jinan University, Guangzhou, P. R. China.

\section{Extraction and isolation}

The air-dried and powdered rhizome (10.0 kg) was extracted four times with $95 \%$ alcohol $(4 \times 35 \mathrm{~L})$ at room temperature. After evaporation of alcohol, the crude extract (492.2 g) was suspended in water $(2 \mathrm{~L})$ and acidified with $\mathrm{HCl}$ to $\mathrm{pH}=4-5$, then partitioned with $\mathrm{CHCl}_{3}(3 \times 4 \mathrm{~L})$ to give a water-soluble fraction. The water-soluble fraction was basified with $\mathrm{NH}_{3} \cdot \mathrm{H}_{2} \mathrm{O}$ to $\mathrm{pH}=9-10$ and then partitioned with a $\mathrm{H}_{2} \mathrm{O} / \mathrm{CHCl}_{3}$ mixture to give a $\mathrm{CHCl}_{3}$-soluble fraction $(63.0 \mathrm{~g})$. The $\mathrm{CHCl}_{3}$ soluble fraction was chromatographed on silica gel column (300-400 mesh, $1000 \mathrm{~g}$ ) eluted with a solvent system of $\mathrm{CHCl}_{3} /$ $\mathrm{CH}_{3} \mathrm{OH}$ (100: 0 to $0: 100, \mathrm{v} / \mathrm{v}$ ), yielding six fractions (Fr.A-F). Fr.B (9.2 g) was further separated on an ODS column (200 g) eluted with $\mathrm{MeOH} / \mathrm{H}_{2} \mathrm{O}$ (30: 70 to $100: 0$, v/v) to afford 9 subfractions (Fr.B1-B9). Fr.B5 (1.2 g) were purified by Sephadex LH$20\left(\mathrm{MeOH} / \mathrm{CHCl}_{3}, 1: 1, \mathrm{v} / \mathrm{v}\right)$ and compound 1 (15.0 mg) was crystallized from the eluent. Then $2(12.3 \mathrm{mg})$ was obtained by the preparative HPLC with $\mathrm{MeOH} / \mathrm{H}_{2} \mathrm{O}(68: 32, \mathrm{v} / \mathrm{v})$ from Fr.B5.

Grandiflodine A (1). Colorless and block crystals $(\mathrm{MeOH})$; $\operatorname{mp} 273-274{ }^{\circ} \mathrm{C} ;[\alpha]_{\mathrm{D}}^{19}+6.8(c 0.6, \mathrm{DMSO}) ; \mathrm{UV}(\mathrm{MeOH}) \lambda_{\max }(\log \varepsilon)$ 208.6 (3.57) nm; IR (KBr) $\nu_{\max } 3480,3423,2933,2876,2228$, 1674, 1462, 1057, 1054, $894 \mathrm{~cm}^{-1}$; ${ }^{1} \mathrm{H}$ and ${ }^{13} \mathrm{C}$ NMR data see Table 1; HRESIMS $m / z \quad 369.2175$ (calcd for $\mathrm{C}_{22} \mathrm{H}_{29} \mathrm{~N}_{2} \mathrm{O}_{3}$, 369.2173).

Grandiflodine B (2). White powder; $[\alpha]_{\mathrm{D}}^{25}+10.7$ (c 0.96, $\mathrm{MeOH}) ; \mathrm{UV}(\mathrm{MeOH}) \lambda_{\max }(\log \varepsilon) 219.5$ (3.78), 250.2 (3.30), 340.5 (3.18) nm; IR (KBr) $\nu_{\max } 3455,2931,2874,1677,1453,1360$, 1189, 1055, $893 \mathrm{~cm}^{-1} ;{ }^{1} \mathrm{H}$ and ${ }^{13} \mathrm{C}$ NMR data see Table 1; HRESIMS $m / z 633.3382$ (calcd for $\mathrm{C}_{33} \mathrm{H}_{49} \mathrm{~N}_{2} \mathrm{O}_{10}, 633.3387$ ).

$\mathrm{X}$-ray crystallographic analysis of 1 . Colorless blocks, $\mathrm{C}_{22} \mathrm{H}_{28} \mathrm{~N}_{2} \mathrm{O}_{3}, M_{\mathrm{r}}=368.46$; monoclinic, space group $P 2_{1} ; a=$

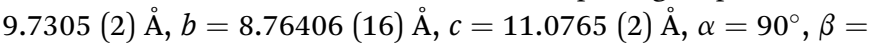
$109.45(2)^{\circ}, \gamma=90^{\circ} ; V=890.68(3) \AA^{3}, Z=2, d_{\mathrm{x}}=1.374 \mathrm{Mg} \mathrm{m}^{-3}$, 
$F(000)=396.0, \mu(\mathrm{Cu} \mathrm{K} \alpha)=0.731 \mathrm{~mm}^{-1}$. Data collection was performed on a Gemini S Ultra using graphitemonochromated radiation $(\lambda=1.54184 \AA$ ) ; 2829 unique reflections were collected to $\theta_{\max }=125.536^{\circ}$, where 14056 reflections were observed $\left[F_{2}>2 \sigma\left(F_{2}\right)\right]$. The structure was solved by direct methods (SHELXS 97) ${ }^{13}$ and refined by full-matrix least-squares on $F_{2}$. Final $R=0.0297, R_{\mathrm{w}}=0.0840$, and $S=1.111$. Crystallographic data for these structures have been deposited with the Cambridge Crystallographic Data Center as CCDC 1517870 for compound 1.

\section{Assay of anti-RSV activities on Hep-2 cells}

The human larynx epidermoid carcinoma (HEp-2, ATCC CCL23) cells and RSV A2 (ATCC VR-1540) strains were purchased from Medicinal Virology Institute, Wuhan University, China. HEp-2 cells were cultured in DMEM (Gibco) supplemented with $100 \mathrm{U} \mathrm{mL}^{-1}$ penicillin and streptomycin solution, and virus was propagated in HEp- 2 cells and incubated in DMEM with $2 \mathrm{mM}$ L-glutamine, $2 \% \mathrm{FBS}$, and $100 \mathrm{U} \mathrm{mL}^{-1}$ penicillin and streptomycin solution. All of the cells were cultured in a 95\% humidified atmosphere supplied with $5 \% \mathrm{CO}_{2}$ at $37{ }^{\circ} \mathrm{C}$, and the ribavirin (Sigma, purity of 99\%) was used as the positive control. The cytotoxicity of the compounds toward HEp-2 cells was detected by the MTT assay in 96-well plates (Corning) with the optical density (OD) values measured in an enzyme immunoassay reader (Thermo Labsystems Multiskan MK3) at $570 \mathrm{~nm}$, and the $50 \%$ cytotoxic concentration $\left(\mathrm{CC}_{50}\right)$ was estimated by regression analysis. The antiviral activities of the isolates against the RSV-A2 strain were assessed by the CPE reduction assay as reported in previous paper. ${ }^{14}$ The concentration that reduces $50 \%$ of $\mathrm{CPE}$ with respect to the virus control was estimated from the plots of the data and was defined as the 50\% inhibitory concentration $\left(\mathrm{IC}_{50}\right)$ of the tested compounds.

\section{Assay of anti-inflammatory activities on NO production toward RAW 264.7 cells}

RAW 264.7 cells were provided by the Medicinal Virology Institute of Wuhan University and maintained in DMEM (Gibco) containing 10\% FBS (Gibco), and supplemented with $100 \mathrm{U} \mathrm{mL}^{-1}$ penicillin and streptomycin solution. Cells were cultured at $37{ }^{\circ} \mathrm{C}$ in a $95 \%$ humidified atmosphere supplied with $5 \% \mathrm{CO}_{2}$. The cytotoxicity of the compounds on RAW 264.7 cells was detected by the MTT assay in 96-well plates with the OD values measured at $570 \mathrm{~nm}$, and the $\mathrm{CC}_{50}$ was estimated by regression analysis. The anti-inflammatory activities of the compounds were evaluated by the inhibitory effect on NO production. RAW 264.7 cells $\left(4 \times 10^{4}\right.$ cells per well) were incubated in a 96-well plate for $14 \mathrm{~h}$ and then pretreated with $100 \mathrm{ng}$ $\mathrm{mL}^{-1}$ LPS and different concentrations of compounds (6.25-
$100 \mu \mathrm{M})$ for $24 \mathrm{~h}$. Then, the Griess reagent $(100 \mu \mathrm{L})$ was added and blended with the supernatant $(100 \mu \mathrm{L})$, and the absorbance was measured at $540 \mathrm{~nm}$ with an enzyme immunoassay reader. NO levels were determined via a calibration curve constructed with $\mathrm{NaNO}_{2}$ concentrations of 3.12-100 $\mu \mathrm{M}$. Inhibitory effects of compounds on NO production $\left(\mathrm{IC}_{50}\right)$ were calculated by regression analysis of the dose-response curve generated from the data.

\section{Acknowledgements}

This work was supported by the National Natural Science Foundation (No. 81473116, 81673319), and Science and Technology Planning Project of Guangdong Province (No. 2016B030301004, 2016A030303011).

\section{Notes and references}

1 K. J. Guan, Editorial committee of Flora of China, Science Press, Flora of China, Beijing, 1979, p. 326.

2 Y. Q. He, Z. Y. Ma, X. M. Wei, D. J. Liu, B. Z. Du, B. H. Yao and L. M. Gao, Chem. Biodiversity, 2011, 8, 2104-2109.

3 X. L. Zhou, D. L. Chen, Q. H. Chen and F. P. Wang, J. Nat. Prod., 2005, 68, 1076-1079.

4 J. G. Diaz, J. G. Ruiz and G. D. Fuente, J. Nat. Prod., 2000, 63, 1136-1139.

5 J. Li, D. L. Chen, X. X. Jian and F. P. Wang, Molecules, 2007, 12, 353-360.

6 T. F. Xu, S. Liu, L. L. Meng, Z. F. Pi, F. R. Song and Z. Q. Liu, J. Chromatogr. B: Anal. Technol. Biomed. Life Sci., 2016, 1026, $56-66$.

7 F. P. Wang, Q. H. Chen and X. Y. Liu, Nat. Prod. Rep., 2010, 27, 529-570.

8 F. Z. Chen, D. L. Chen, Q. H. Chen and F. P. Wang, J. Nat. Prod., 2009, 72, 18-23.

9 K. J. Guan, Editorial committee of Flora of China, Science Press, Flora of China, Beijing, 1979, p. 445.

10 L. Yang, Y. B. Zhang, L. Zhuang, T. Li, N. H. Chen, Z. N. Wu, P. Li, Y. L. Li and G. C. Wang, Planta Med., 2017, 83, 111-116.

11 S. W. Pelletier, S. W. Page and M. G. Newton, Tetrahedron Lett., 1970, 55, 4825-4827.

12 J. Lu, H. K. Desai, S. A. Ross, H. M. Sayed and S. W. Pelletier, J. Nat. Prod., 1993, 56, 2098-2103.

13 G. M. Sheldrick, SHELXS-97: Manual of Program for the Refinement of Crystal Structures, University of Göttingen, Germany, 1997.

14 H. W. Geng, X. L. Zhang, G. C. Wang, X. X. Yang, X. Wu, Y. F. Wang, W. C. Ye and Y. L. Li, J. Asian Nat. Prod. Res., 2011, 13, 665-669. 